Article

\title{
Assessing the Vulnerabilities of Current and Future Production Systems in Punjab, Pakistan
}

\author{
Syed Asif Ali Naqvi ${ }^{1, *(\mathbb{D}}$, Abdul Majeed Nadeem ${ }^{1, *}$, Muhammad Amjed Iqbal ${ }^{2}$, Sadia Ali ${ }^{1}$ \\ and Asia Naseem ${ }^{1}$ \\ 1 Department of Economics, Government College University Faisalabad, Faisalabad 38040, Pakistan; \\ sadiaali@gcuf.edu.pk (S.A.); asiagcuf@yahoo.com (A.N.) \\ 2 Institute of Agricultural and Resource Economics, University of Agriculture, Faisalabad 38040, Pakistan; \\ amjed.iqbal@uaf.edu.pk \\ * Correspondence: syedasif_1@yahoo.com (S.A.A.N.); majeednadeem@gcuf.edu.pk (A.M.N.); \\ Tel.: +92-300-4691512 (S.A.A.N.)
}

Received: 3 September 2019; Accepted: 24 September 2019; Published: 27 September 2019

check for updates

\begin{abstract}
Mankind is in peril and there are many reasons for this; however, climate change precedes all other reasons. Problems of poor farming communities are augmented due to the menace of climate change. This study endeavors to determine the effect on farming communities of both climate change and a situation without climate change. To carry out the study, three different districts were selected (Rawalpindi, Chakwal, and Layyah). Impact of the climate vagaries on per capita income, farm returns, and poverty of the respondents was taken into consideration. To achieve pathways analysis, regional representative agricultural pathways were used. The decision support system for agrotechnology transfer (DSSAT) crop growth model was employed for wheat-related simulations. The tradeoff analysis model for multidimensional impact assessment (TOA-MD) model was used for economic analysis. The results lend credence to the aforementioned nuisance of climate change, as the findings which came through were negatively affecting farm returns, per capita income, and poverty of the farmers. The negative impact applies to both current and future production systems. Farmers are up against the wall because of climate change and they will have to adopt new innovations to raise their productivity.
\end{abstract}

Keywords: climate; Punjab; adaptations; poverty; income; wheat

\section{Introduction}

Poor farming communities relying on the agriculture sector for their livelihood are prone to climate change [1]. They have to work in an environment that is vulnerable to different types of uncertainties caused by the natural environment [2]. The rising temperature and its variation are the main factors which explain the cycles of crop productivity. As a result of the changing environment, the duration of seasons is increasing intermittently, and the agriculture sector's productivity is decreasing [3]. There is a significant impact of global warming (temperature and carbon emission) on the productivity of the agriculture sector with the passage of time. A grower cannot attain a sustainable level of production in the agriculture sector without assessing climate change [4]. Climate variation is a worldwide threat to the environment and development. With the passage of time, agricultural productivities simmered down due to the emission of unfavorable gases such as carbon dioxide and methane.

Crops can be more vulnerable to environmental and climate changes, which results in an adverse impact on crop productivity, as well as farmers' livelihood and dwindling farm income [5]. According to Reference [4], developing nations are facing more issues related to climate change (CC) due to a low adaption rate. According to an estimation, CC is expected to affect food security in the mid-21st 
century. In south Asia, this problem is even more serious [6]. If the status quo persists in the future, then cereal crop production could decline up to $30 \%$ in the year 2060 [7]. The increasing trend in the global and regional level temperature is the main cause encouraging early plantation, early maturity, and early harvesting. Likewise, the increasing trend in night-time respiration is also responsible for a decline in the productivity of agri-products, as well as crop cycles [8].

Due to a shortage of food, the farming community is seriously focusing on raising production, as the world population is expected to rise to nine billion in the mid-21st century, along with the degrading quality of the environment and ecosystem. This challenge can be overcome by introducing adaptations against climate change to offset the negative impacts. These vulnerabilities and risks at the farm level can be categorized into different types, according to their nature and the crops involved. In agro-based countries like Pakistan, the agriculture sector after an improvement in its productivity could play a role in future economic development by raising living standards and alleviating poverty [9]. The world may face serious adverse results from CC in the near future and, due to these changes, global food security will also be a big challenge in the future $[10,11]$.

Farming is a vital provider of livelihood for communities that are directly or indirectly connected with this sector [12]. The negative impacts of climate on agriculture production systems should be compensated for to secure society from food insecurity and protect it from vulnerability to CC $[13,14]$. Cropping patterns are changing in developing countries due to different factors affecting agricultural production systems. The global population is increasing day by day and is expected to reach 9.2 billion by 2050 from 6.5 billion today, and the population of Pakistan is predicted to cross the 300-million threshold by 2050 [15]. Industrialization and rural-to-urban migration are also worsening the situation in the developing world. Developing economies like Pakistan are mostly dependent on labor-intensive technologies and, due to this fact, they are more sensitive and vulnerable to climate change; on the other hand, developed economies have advanced types of technologies, which they use for getting a higher level of agricultural productivity $[16,17]$. The rapidly increasing population, declining per capita arable land, and water availability are the main dilemmas facing Pakistan's agriculture [18]. Traditional agriculture production systems face serious challenges such as acute water shortages due to CC. The changing weather patterns also reduce growing seasons [19]. The likelihood of water scarcity as a result of CC alone might be higher than $90 \%$, which will reduce water availability by more than $10 \%$ in Pakistan [20].

In the past decade, Pakistan faced drought, flooding, extreme changes in temperature, environmental degradation, and many other climatic changes. Thus, there are number of climatic factors which influence the agricultural productivity in Pakistan, such as carbon emissions, rainfall, and rising temperature with the passage of time. The level of hazard due to CC in Pakistan is at a serious level, and the situation may worsen in the future. It is, therefore, important to measure the socio-economic impacts of these shocks of CC on all vulnerable systems, particularly on the agriculture sector. Similarly, weather conditions represent the main sector exhibiting an inverse relationship with the economic sector; thus, agriculture is vulnerable to CC with the passage of time [21]. Floods and dry spells are destroying the agriculture in Pakistan, causing harm to livelihood and health [22].

According to literature, Pakistan is included in the nations vulnerable to CC. Pakistan is ranked 12th by the Global Climate Risk Index due to its exposure to extreme weather events. The World Bank also graded Pakistan at 12th in a list of highly climate-affected countries [23]. In spite of its significant contribution to the global economy, Pakistan still faces serious problems due to climatic variations, i.e., increasing temperature, droughts, floods, and an overall loss in net returns [24]. In developing countries like Pakistan, the majority of people living in rural areas are directly connected to the agriculture sector. Hence, adaptation to CC is necessary for the sake of food security and to ensure the livelihood of people living in rural areas. Pakistan is the second biggest nation in south Asia and 36th biggest in the world. The total area of Pakistan is 79.6 million hectares, of which more than one-fourth is under cultivation (approximately 22 million hectare), while only 19 million hectares encompass irrigated area. Agricultural produce is the main source of income for the majority of the 
small farmers. To manage climate changes at the farm level, the attitude of the farmers toward these changes can play an important role $[25,26]$. In particular, wheat as a staple food in the world has much more importance than any other crop. The European Union is at the top with respect to wheat production, whereas Pakistan is ranked eighth. In Pakistan, total production was 2547 million metric tons in the year 2018, while annual wheat consumption was 24,500 metric tons. This highlights the importance of ensuring wheat production by analyzing the vulnerabilities of the current production system and protecting it from the adverse impacts of climatic changes in the near future. Pakistan is facing serious climate change, including consecutive floods since 2010 and excessive rainfall. All these factors cause not only loss to the farming sector but might increase vulnerability toward hunger and food insecurity. Moreover, farmers are lacking the capacity for adaptation toward these vulnerabilities and uncertainties due to a lack of resources and financial constraints $[27,28]$.

Numerous studies examined the impact of climate change on agriculture (e.g., References [29-39]). These studies outlaid the impact of climate variables on the productivity of agriculture and farmers' revenue. References [40,41] estimated climate change adaptation's impact on crop revenue, food productivity, and determinants of climate change adaptation. Their studies revealed that farming experience and education are likely to have a significant impact on a farmer's decision to adapt. These studies further explored a positive impact of adaptations on food productivity and net agriculture returns. Determinants of different adaptation strategies and their impact on food security and poverty level were quantified by References [35,42]. The impact of CC was assessed by Reference [43] on the food security of rural households. Results of the food balance model showed that more than $80 \%$ of rural households were food-insecure due to CC.

The direct and indirect impacts of climate change on agricultural productivity were explored by Reference [44], and it was found that there is a significant impact of climate variability on agriculture output. Reference [45] estimated the impact of these changes on the farming sector and concluded that climate variability could have a negative impact on food productivity and could cause food insecurity. In their research, the authors of Reference [46] used the revised Indus Basin Model (IBMR) to check the impact of climate change on water availability and food security in Pakistan and found out that Sindh is more vulnerable to climate variabilities than other provinces. The influence of CC on rice yield in light of several carbon dioxide emission scenarios was assessed by Reference [40]. Furthermore, Reference [47] estimated the impact of climate variability on the output of different varieties of rice crop. Their results indicated that there is a statistically significant relationship between precipitation and the output of rice. The impact of CC on agriculture was examined by Reference [48], finding that temperature has a negative impact on net returns, whereas rainfall is likely to have a positive impact on net returns. The impact of temperature and precipitation on wheat productivity was estimated by Reference [49], and it was found that there are relationships among change in temperature, precipitation, area under wheat cultivation, water, carbon dioxide, and wheat yield. The influence of CC on wheat yield was estimated by Reference [50] for Pakistan, and it was concluded that there is a negative impact of temperature on the yield of wheat crop.

The specific contribution of this study is that it is the first attempt of its kind to evaluate the existing vulnerability level and its allied impacts on net returns, per capita income, and poverty levels for cases with and without climate change in the rain-fed region of Pakistan. Similarly, following the standard ex ante set of methodology, we tried to quantify the future vulnerability levels, as well as its allied impacts on selected economic indicators for a longer period of time. Although some previous studies analyzed the cropping system, a specific and in-depth study focusing on the rain-fed region of Punjab is missing in the existing literature despite this region being more prone and vulnerable to the changing climate, as well as water-deficient scenarios in Pakistan. This will be helpful for developing strategies to combat the adverse effects of CC and water deficiency to develop a sustainable development production system in Punjab, Pakistan.

For small farmers, adaptations to climatic variations are significant measures that can decrease the vulnerability and adverse impacts of extreme weather events, helping them to protect themselves, 
as well as their farming systems $[27,28]$. Due to a lack of capital and less technological development, support for the agriculture sector in terms of adaptation is limited to some extent $[27,28]$. Adaptations to CC are needed in today's world, and substantial research was carried out in different regions of world $[29,30]$. Perceiving CC is the foremost step in the procedure of adapting agriculture to climate changes [31]. Although a lot of research was done on adaptations to CC on an international level, few studies were carried out in south Asia, especially in rain-fed regions of Pakistan. Likewise, very few studies are available to consider farmers' behavior toward adaptations of climate change in the agriculture sector in Pakistan [34]. The comprehensive knowledge from this study might be helpful for policy-makers to assess how our production system is currently vulnerable to climate changes and what could be the scenario in the future. The research implications of the current study will ensure a way forward to sustainable development in the agriculture production system. The conventional (ex post) approach is inferior to the new estimation technique (ex ante); thus, this study focuses on the novel technique for the estimation of economic and CC impacts on agricultural production.

\section{Materials and Methods}

In our analysis, we focused on climate variability, which is expected to affect the wheat production in the arid agricultural zone of Punjab province in Pakistan. In the analysis, three districts, i.e., Chakwal, Layyah, and Rawalpindi, were included. For this purpose, various socio-economic indicators were measured that are impacted by CC, including per capita income, mean net farm returns, and poverty rate for current and future production systems. An extensive field survey was conducted for study purposes. The household $(\mathrm{HH})$ data were collected from the farming communities of the study area during the survey. The stratified random sampling technique was applied for sampling purposes, as data were heterogeneous in nature. At least 30 farms were selected from each district, and a total sample of 105 farmers was taken. Current and future time periods for crop simulations were 1980-2010 and 2040-2069, respectively, following the methodology of References [18,51,52]. The main staple crop (wheat) was taken to represent major farming activity.

Wheat crop yield simulations (baseline, current, and future) for the integrated economic impact assessment were quantified using five general circulation models (GCMs), i.e., CM2 BNU, CCSM4, CMCC, GFDL, and INMCM4, and these were the components of inter-comparison projects (CMIPs) [51,52]. In the crop growth model, the productivity created by GCMs was used as input. The decision support system for agrotechnology transfer (DSSAT) v4.6.1 crop growth model was employed for wheat-related simulations [52]. The DevRAP matrix and other data related to modeling were taken from the Agricultural Model Intercomparison and Improvement Project (AgMIP) Pakistan database with their prior permission [18].

Various techniques are used for climate change assessment such as the global change assessment model, integrated assessment model, and tradeoff analysis model for multidimensional impact assessment model (TOA-MD). The impact of environmental changes can be estimated using the various models. The TOA-MD model is used widely for the estimation and assessment of socio-economic and climatic impacts for crops, livestock, and aquaculture systems [53,54]. Due to multi-dimensional impact evaluation, this model is used for various estimations rather than just for CC. The adoption and impacts of new technologies can be explained using this model in the agriculture sector [22,55]. The root-mean-square error (RMSE) and $d$-index were also calculated. RMSE indicates the size of the error produced by the model, a model performance assessment criterion. The enhanced Willmott concordance index $(d)$ shows the deviation between the observed and simulated values.

This study used the TOA-MD model for analyzing the socio-economic impacts of CC. This model depends on data from different sources, including cross-sectional data of farmers, experimental and biophysical model outputs, and concerned stakeholder opinions. This model has some advantages over other models; for example, it explains all reasons that growers systematically select for adoption or vice versa during technology selection. The adoption of and payments for environmental services were explained as the basis of this model [52], which can also be used for CC applications. 
Production systems (technology) and CC are the two main factors, and it is essential to differentiate them. In CC analysis, a system is basically related to production and its specific technology employed in a given climate time period. This is why net farm returns $v_{t}$ are calculated in a CC study for every time period as follows:

$$
v_{t}=v_{t}(p, s, h) .
$$

In Equation (1), the probable prices are expected to not fluctuate over a specific time period [51-54]. Thus, it can be written that, for $\mathrm{T}$ time periods, system $h$ provides a discounted net return $\mathrm{V}$ as given below.

$$
\begin{gathered}
V(p, s, h)=\sum \delta_{t} v_{t}(p, s, h) . \\
\mathrm{T}=1
\end{gathered}
$$

In Equation (2), $\delta_{t}$ is the discount factor. We can distribute time into two periods, developing a separate system for both periods. If some of the HHs are losing their incomes and getting poor over time due to these changes, it means that they are vulnerable to CC in the future. Generally, climate changes could be estimated on the basis of the number of farmers that will face losses in the future [52-55]. According to the model, HHs make their choices to either continue their current production system or alternatively shift to a new system. This is based on the opportunity cost, written in the form of the equation below.

$$
\omega=\mathrm{v}_{1}-\mathrm{v}_{2}
$$

where $v_{1}$ and $v_{2}$ are the net returns from the original and alternate systems, respectively. HHs will switch to an alternate system if their opportunity cost is less than 0 . On the other hand, they will prefer to continue employing the current technology where $\omega$ is positive, as shown in Equation (4).

$$
\sigma_{\omega}^{2}=\sigma_{1}^{2}+\sigma_{2}^{2}-2 \sigma_{1} \sigma_{2} \rho_{12}
$$

Another important indicator is the correlation that exists between both systems (Equation (5)).

$$
\rho_{12}=\mu_{\beta} \sigma_{1} /\left(\mu_{\beta}{ }^{2} \sigma_{1}{ }^{2}+\sigma_{\beta}{ }^{2}\left(\sigma_{1}{ }^{2}+\mu_{1}^{2}\right)\right)^{1 / 2} .
$$

Model parameters for future production or alternative systems can be calculated using the methodology of Reference [52]. Similar methods were employed by References [55,56] for analysis.

$$
\begin{gathered}
\mu_{1 j}=\beta_{\mathrm{yk}} \cdot \psi_{1 \phi} \cdot \Gamma, \\
\mathrm{R}_{1 \mathrm{j}}=\phi_{1} \cdot \mathrm{p}_{1} \cdot \mathrm{a}_{1 \mathrm{j}} \cdot \mu_{1 \mathrm{j}}, \\
\mathrm{G}_{1 \mathrm{j}}=\beta_{\mathrm{ck}} \cdot \Psi \cdot \mathrm{C}_{1 \mathrm{j}} / \mathrm{R}_{1}, \\
\mathrm{~V}_{1 \mathrm{j}}=\mathrm{R}_{1 \mathrm{j}}-\beta_{\mathrm{ck}} \cdot \Psi \cdot \mathrm{C}_{1 \mathrm{j}},
\end{gathered}
$$

where $\Gamma=1, \phi_{1}=1, \Psi=1$ for simple CC-IA, $\mathrm{p}_{1}$ is the illustrative price adjusted to the present time period, and $\beta_{\mathrm{k}}$ is a normalization factor.

$$
\begin{gathered}
\mu_{2 j}=r_{j} \cdot \mu_{1 j}, \\
R_{2 j}=\phi_{2} \cdot p_{2} \cdot a_{2 j} \cdot \mu_{2 j}, \\
C_{2 j}=G_{1 j} \cdot R_{2 j}, \\
V_{2 j}=R_{2 j}-C_{2 j}=\left(1-G_{1 j}\right) \cdot R_{2 j},
\end{gathered}
$$

where $\mu_{1 \mathrm{j}}$ is the time-averaged (TA) mean of production/acre, $\mu_{2 \mathrm{j}}$ is the TA mean of production/acre $\mathrm{y}_{2 \mathrm{jt}}$ for farm $j$ with $C C, Y_{1 k}$ is the mean of observed production/acre $y_{1 j k}$ in the data for base year $k, Y_{1}$ is the mean of production/acre, $\Psi$ is the compounded production/acre growth factor (GF), $\Phi \mathrm{h}$ is the 
compounded price GF amid selected time periods, $\Psi$ is the compounded variable production cost GF, $\beta_{\mathrm{yk}}=\mathrm{Y}_{1} / \mathrm{Y}_{1 \mathrm{k}}$ is a normalization factor, $\mathrm{s}_{\mathrm{hjt}}$ is the simulated wheat production per acre for system $\mathrm{h}$, farm $\mathrm{j}$, in year $\mathrm{t}(\mathrm{kg} /$ farm $), \mathrm{s}_{1 \mathrm{j}}$ is the simulated wheat production/acre, $\mathrm{s}_{2 \mathrm{j}}$ is the TA simulated wheat production/acre with CC, $b_{\text {hjt }}=s_{\text {hjt }} / y_{\text {hjt }}$ is the bias in simulated wheat yield, $r j=s_{2 j} / s_{1 j}$ is the relative yield (kg), $a_{h j t}$ is the total wheat crop area, $R_{h j t}$ is the revenue $=p_{h t} \cdot y_{h j t} \cdot a_{h j t}(R s . / f a r m / s e a s o n), R_{h j}$ is the TA revenue (PKR/farm/season), $\mathrm{C}_{\mathrm{hjt}}$ is the production cost (PKR/farm/season), $\mathrm{C}_{\mathrm{hj}}$ is the TA production $\operatorname{cost}\left(\mathrm{PKR} /\right.$ farm), $\mathrm{C}_{1}$ is the mean of production cost (PKR), $\beta_{\mathrm{ck}}=\mathrm{C}_{1} / \mathrm{C}_{1 \mathrm{k}}$ is a normalization factor used to scale production cost, $G_{h j t}=C_{h j t} / R_{h j t}$ is the production cost relative to revenue (PKR), $G_{h j}=C_{h j} / R_{h j}$ is the TA production cost, $V_{h j t}=R_{h j t}-C_{h j t}$ is the wheat net returns for the farm (PKR/season), and $V_{h j}$ is the mean of $V_{\text {hjt }}$ over the current or future time (PKR).

Average yield variation in wheat $($ percent $)=($ average relative production per acre -1$) \times 100$.

For the study, regional pathways developed by AgMIP Pakistan [18] were used. Trend factors from "International Model for Policy Analysis of Agricultural Commodities and Trade" (IMPACT) by References [55-57] were merged with regional Representative Agricultural Pathways (RAPs) for the sake of consistency with universal models, as done by References [18,55]. In both types of analyses, the poverty line was United States $\$ 1.25$ /person for each day. During RAP analysis, trend factors of yields, prices, and costs were incorporated. These values were in real terms, based on the year 2005 in United States dollars. These were incorporated in order to observe the impact of CC in the future, while considering technological improvements.

\section{Results}

In this section, findings of the study are given. For all selected GCMs, outcomes of each selected stratum are discussed first, and then results for the whole farming population area are given. Each table contains two parts; the first part describes the results of climate sensitivity analysis, and the second part depicts the results of the model for the future production system after the inclusion of RAPs.

In Table 1, quantifications of the model for CC impact assessment are given first. According to the results, it is clear that up to $60.9 \%$ of $\mathrm{HHs}$ would be vulnerable in the future due to climatic variabilities. The profits and losses (percentage mean net farm return) would be $28.7 \%$ and $36.3 \%$, respectively. The observed net returns (NRs) without CC were Rs. 0.14 million/farm and, under a climate change scenario, these would decrease to Rs. 0.12 million (M)/farm. The observed per capita income (PCI) without CC was up to Rs. 8000/person and, for the second case, it was reduced to Rs. 7000 . The poverty rate without CC was up to $24 \%$, and, under CC, it elevated to $25.3 \%$ for the study area.

Table 1. Impact of climate on the current and future agricultural production systems (GCM CM2 BNU).

\begin{tabular}{|c|c|c|c|c|c|c|c|c|c|c|}
\hline Strata & $\begin{array}{c}\text { \%HOUSEHOLD } \\
\text { (HH) } \\
\text { Vulnerable }\end{array}$ & $\begin{array}{c}\text { Gains } \\
(\%)\end{array}$ & $\begin{array}{c}\text { Losses } \\
(\%)\end{array}$ & $\begin{array}{c}\text { Net } \\
\text { Impact } \\
(\%)\end{array}$ & $\begin{array}{l}\text { Net Returns } \\
\text { (NR) without } \\
\text { Climate } \\
\text { Change (CC) } \\
\text { (Rs.) }\end{array}$ & $\begin{array}{l}\text { NR with CC } \\
\text { (Rs.) }\end{array}$ & $\begin{array}{l}\text { Per Capita } \\
\text { Income } \\
\text { (PCI) } \\
\text { without CC }\end{array}$ & $\begin{array}{l}\text { PCI } \\
\text { with } \\
\text { CC }\end{array}$ & $\begin{array}{l}\text { Poverty } \\
\text { without } \\
\text { CC } \\
(\%)\end{array}$ & $\begin{array}{l}\text { Poverty } \\
\text { with } \\
\text { CC } \\
(\%)\end{array}$ \\
\hline \multicolumn{11}{|c|}{ Climate Change Impacts } \\
\hline Rawalpindi & 60.9 & 25.6 & 33.0 & -7.3 & $144,514.6$ & $129,958.4$ & $18,291.6$ & $16,730.9$ & 57.7 & 61.6 \\
\hline Chakwal & 59.7 & 36.9 & 46.1 & -9.2 & $142,234.2$ & $124,255.3$ & $20,251.9$ & $17,985.9$ & 52.3 & 56.3 \\
\hline Layyah & 60.1 & 23.3 & 29.5 & -6.2 & $130,471.2$ & $119,461.2$ & $17,234.5$ & $16,020.9$ & 60.9 & 64.1 \\
\hline Aggregate & 60.2 & 28.7 & 36.3 & -7.6 & $139,192.3$ & $124,675.9$ & 7766.8 & 7063.0 & 20.0 & 25.3 \\
\hline \multicolumn{11}{|c|}{ Representative Agricultural Pathways } \\
\hline Rawalpindi & 46.0 & 20.0 & 18.3 & 1.7 & $310,225.9$ & $317,620.1$ & $28,642.0$ & $29,264.9$ & 36.3 & 35.0 \\
\hline Chakwal & 47.1 & 24.1 & 22.5 & 1.6 & $322,270.2$ & $329,194.6$ & $33,937.1$ & $34,622.8$ & 32.0 & 30.9 \\
\hline Layyah & 44.7 & 18.4 & 16.3 & 2.1 & $275,166.0$ & $283,031.3$ & $26,460.3$ & $27,148.4$ & 39.0 & 37.2 \\
\hline Aggregate & 46.0 & 20.9 & 19.1 & 1.8 & $302,723.9$ & $310,118.4$ & $12,383.0$ & $12,656.7$ & 14.9 & 14.3 \\
\hline
\end{tabular}

In the case of a future production system and the current climate scenario, losses were reduced to $46 \%$ as compared to the CC impact assessment analysis where these were $60 \%$. The profits and losses (percentage mean net farm return) would be $20.9 \%$ and $19.1 \%$, respectively. NRs without and with CC 
were Rs. $0.302 \mathrm{M} /$ farm and Rs. $0.31 \mathrm{M} /$ farm, respectively. PCI without CC would be Rs. 12,300/person and, in the other case, it would increase to Rs. 12,600/person/season. A negligible decrease in the rate of poverty was also observed in this case.

Table 2 depicts the outcomes of the model for CC impact assessment for GCM CCSM4. According to the results, it is clear that up to $65 \%$ of $\mathrm{HHs}$ would be vulnerable in the future due to climatic variabilities. The profits and losses (percentage mean net farm return) would be $26.9 \%$ and $38.6 \%$, respectively. The observed NRs without CC were RS. $0.14 \mathrm{M} / \mathrm{farm}$, and, under CC, these would reduce to RS. $0.12 \mathrm{M} /$ farm. PCI without climate change would be RS. 9500 and, in the case of the second system, PCI would decline to RS. 8000/person/season. The poverty rate with the existing climate would be $20 \%$, and, after CC, this would increase to $22.4 \%$.

Table 2. Impact of climate on current and future agricultural production systems (GCM CCSM4).

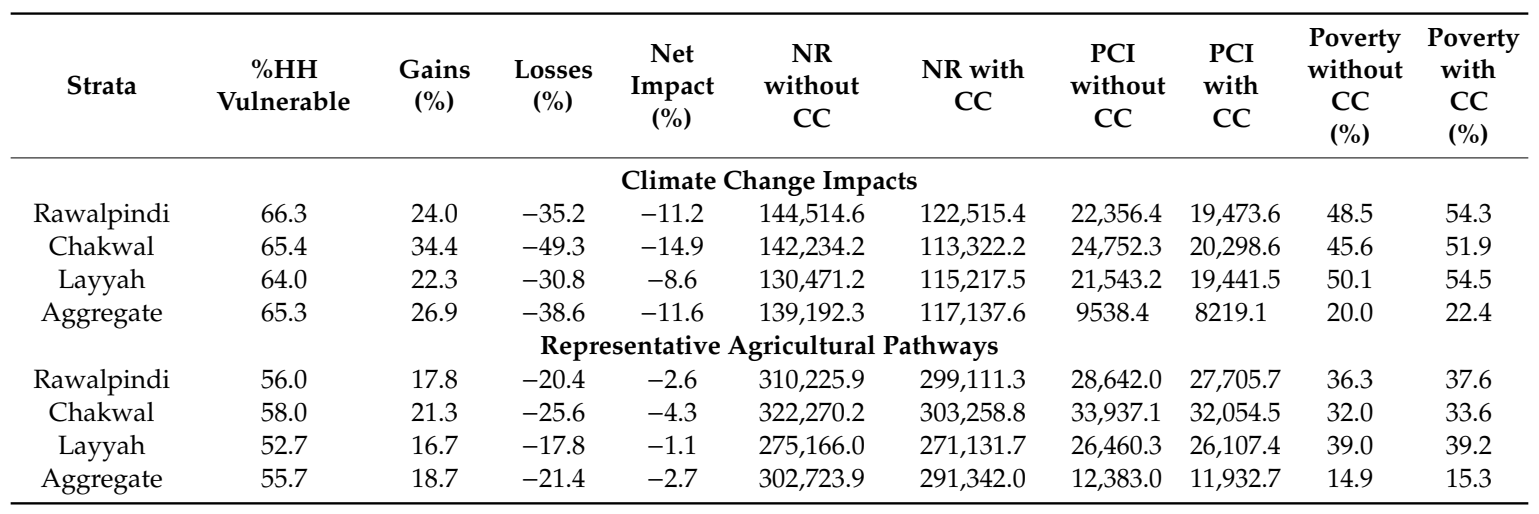

In the case of a future production system and the current climate scenario, up to a $9 \%$ reduction in the losses was observed. Here, $45 \%$ of HHs would remain in the current system due to facing losses following these changes. The profits and losses (percentage mean net farm return) would be $18.7 \%$ and $21.4 \%$, respectively. Net returns without and with climate change were RS. $0.302 \mathrm{M} / \mathrm{farm}$ and RS. $0.29 \mathrm{M} /$ farm, respectively. PCI without CC was approximately RS. 12,300/person and, under CC, the per capita income would decrease to RS. 11,900/person/season. A negligible increase in the rate of poverty was also observed in this case.

In Table 3, quantifications of the model for CC impact assessment for GCM CMCC are given. It is clear that up to $68 \%$ of $\mathrm{HHs}$ would be vulnerable in the future due to climatic variabilities. The profits and losses (percentage mean net farm return) would be $25.9 \%$ and $40.2 \%$, respectively. The observed net returns without CC were RS. $0.14 \mathrm{M} /$ farm and, under CC, these would reduce to RS. $0.11 \mathrm{M} /$ farm after climatic variabilities. The observed PCI without climate variabilities would be RS. 9000 per person and, after climatic variabilities in the future, PCI would decline to RS. 7000 per person/season. In the case of poverty rate, it would increase from $20 \%$ to $23 \%$ going from the first to second.

Table 3. Impact of climate on current and future agricultural production systems (GCM CMCC).

\begin{tabular}{|c|c|c|c|c|c|c|c|c|c|c|}
\hline Strata & $\begin{array}{c}\% \mathrm{HH} \\
\text { Vulnerable }\end{array}$ & $\begin{array}{c}\text { Gains } \\
(\%)\end{array}$ & $\begin{array}{c}\text { Losses } \\
(\%)\end{array}$ & $\begin{array}{c}\text { Net } \\
\text { Impact } \\
(\%)\end{array}$ & $\begin{array}{c}\text { NR } \\
\text { without } \\
\text { CC }\end{array}$ & $\begin{array}{l}\text { NR with } \\
\text { CC }\end{array}$ & $\begin{array}{c}\text { PCI } \\
\text { without } \\
\text { CC }\end{array}$ & $\begin{array}{c}\text { PCI } \\
\text { with } \\
\text { CC }\end{array}$ & $\begin{array}{c}\text { Poverty } \\
\text { without } \\
\text { CC } \\
(\%)\end{array}$ & $\begin{array}{c}\text { Poverty } \\
\text { with } \\
\text { CC } \\
(\%)\end{array}$ \\
\hline \multicolumn{11}{|c|}{ Climate Change Impacts } \\
\hline Rawalpindi & 69.6 & 23.1 & -36.7 & -13.7 & $144,514.6$ & $117,683.5$ & $22,356.4$ & $18,840.4$ & 48.5 & 55.6 \\
\hline Chakwal & 67.8 & 33.4 & -50.9 & -17.5 & $142,234.2$ & $108,451.5$ & $24,752.3$ & $19,548.3$ & 45.6 & 53.0 \\
\hline \multicolumn{11}{|c|}{ Representative Agricultural Pathways } \\
\hline Rawalpindi & 62.5 & 16.5 & -22.1 & -5.6 & $310,225.9$ & $286,559.9$ & $28,642.0$ & $26,648.4$ & 36.3 & 39.5 \\
\hline Chakwal & 62.2 & 22.1 & -29.3 & -7.2 & $322,270.2$ & $290,488.5$ & $33,937.1$ & $30,789.8$ & 32.0 & 35.3 \\
\hline Layyah & 60.5 & 15.4 & -19.7 & -4.3 & $275,166.0$ & $259,104.7$ & $26,460.3$ & $25,055.2$ & 39.0 & 41.4 \\
\hline Aggregate & 61.8 & 18.2 & -23.9 & -5.7 & $302,723.9$ & $278,890.1$ & $12,383.0$ & $11,467.0$ & 14.9 & 16.1 \\
\hline
\end{tabular}


In the case of a future production system and the current climate scenario (Table 3), it is clear that up to $62 \%$ of people would face a reduction in their productivities and, ultimately, they would face a reduction in their income. However, these losses were less than the losses of the simple climate change system. The profits and losses (percentage mean net farm return) would be $18.2 \%$ and $23.9 \%$, respectively. Net returns without and with climate change were RS $0.302 \mathrm{M} /$ farm and RS. $0.28 \mathrm{M} / \mathrm{farm}$, respectively. PCI without CC was approximately RS. 12,300/person and, under CC, per capita income would increase to RS. 11,400/person/season. A $2 \%$ increase in the level of poverty was also observed.

Quantifications of the model for CC impact assessment are given in Table 4. According to the results, it is clear that up to $67 \%$ of $\mathrm{HHs}$ would be vulnerable in the future due to climatic variabilities while considering the current production system. The profits and losses (percentage mean net farm return) would be $27 \%$ and $39 \%$, respectively. The observed net returns without CC were RS. $0.14 \mathrm{M} / \mathrm{farm}$ and, under CC, these would change to RS. $0.11 \mathrm{M} /$ farm in the future. PCI with the current climate was approximately RS. 9500/person. Under CC, PCI would decline to RS. 8000/person/season. The poverty rate with the current and future climate would be $20 \%$ and $23 \%$, respectively.

Table 4. Impact of climate on current and future agricultural production systems (GCM GFDL).

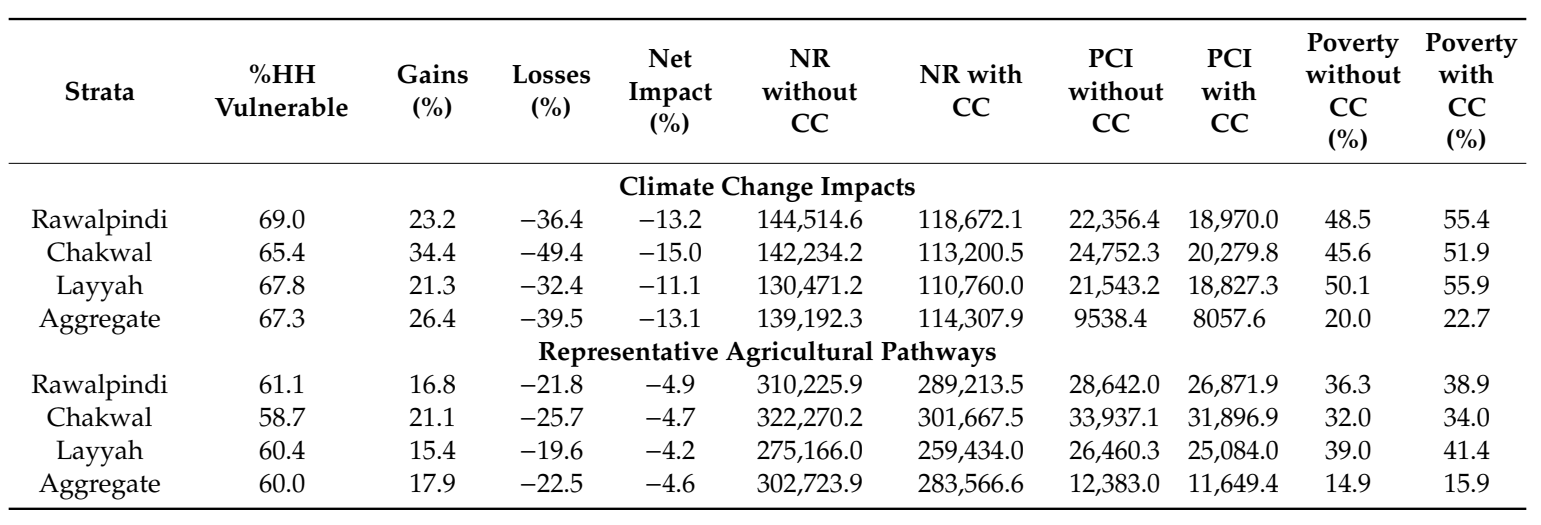

In the case of RAP analysis, the story is different from CC impact assessment. Here, although HHs would face elevated poverty levels, they would be significantly better than the first case. Here, $60 \%$ of the sampled population would face losses; however, these were $67 \%$ in the future. The profits and losses (percentage mean net farm return) would be $17.9 \%$ and $22.5 \%$, respectively. Net returns without and with climate change were RS. $0.302 \mathrm{M} /$ farm and RS. $0.28 \mathrm{M} /$ farm, respectively. PCI without CC was approximately RS. 12,300/person and, under CC, per capita income would increase to RS. $11,600 /$ person/season. A negligible increase $(1 \%)$ in the rate of poverty was also observed in this case.

In Table 5, quantifications of the model for CC impact assessment are given first. According to the results, it is clear that up to $66 \%$ of $\mathrm{HHs}$ would be vulnerable in the future due to climatic variabilities. The profits and losses (percentage mean net farm return) would be $27 \%$ and $39 \%$, respectively. The observed net returns were RS. 0.14 and RS. $0.12 \mathrm{M} /$ farm for cases without and with CC, respectively. PCI without climate change would be RS. 8000 per person. After CC, this would decrease to RS. 7000 . For the current time period, poverty is $20 \%$, and, in the case of climate change, it would increase by $3 \%$ compared to the prior case.

In the case of analysis incorporating RAPs and the current climate scenario, non-adopters would represent $55 \%$. The profits and losses (percentage mean net farm return) would be $19 \%$ and $21 \%$, respectively. Net returns without and with climate change were RS. $0.302 \mathrm{M} /$ farm and RS. $0.29 \mathrm{M} / \mathrm{farm}$, respectively. PCI without CC was approximately RS. 12,300/person and, under CC, it could decrease to RS. 12,000/person/season. A negligible increase in the rate of poverty was also observed in this case. Mean net farm returns (percentage) are given for current and future agricultural production systems in the Figure 1. 
Table 5. Impact of climate on current and future agricultural production systems (GCM INMCM4).

\begin{tabular}{|c|c|c|c|c|c|c|c|c|c|c|}
\hline Strata & $\begin{array}{c}\% \mathrm{HH} \\
\text { Vulnerable }\end{array}$ & $\begin{array}{c}\text { Gains } \\
(\%)\end{array}$ & $\begin{array}{c}\text { Losses } \\
(\%)\end{array}$ & $\begin{array}{c}\text { Net } \\
\text { Impact } \\
(\%)\end{array}$ & $\begin{array}{c}\text { NR } \\
\text { without } \\
\text { CC }\end{array}$ & $\begin{array}{l}\text { NR with } \\
\text { CC }\end{array}$ & $\begin{array}{c}\text { PCI } \\
\text { without } \\
\text { CC }\end{array}$ & $\begin{array}{c}\text { PCI } \\
\text { with } \\
\text { CC }\end{array}$ & $\begin{array}{c}\text { Poverty } \\
\text { without } \\
\text { CC } \\
(\%)\end{array}$ & $\begin{array}{c}\text { Poverty } \\
\text { with } \\
\text { CC } \\
(\%)\end{array}$ \\
\hline \multicolumn{11}{|c|}{ Climate Change Impacts } \\
\hline Rawalpindi & 71.5 & 22.5 & -37.7 & -15.2 & $144,514.6$ & $114,833.5$ & $22,356.4$ & $18,467.0$ & 48.5 & 56.4 \\
\hline Chakwal & 63.8 & 35.1 & -48.4 & -13.3 & $142,234.2$ & $116,314.1$ & $24,752.3$ & $20,759.5$ & 45.6 & 51.2 \\
\hline Layyah & 62.9 & 22.6 & -30.5 & -7.9 & $130,471.2$ & $116,405.9$ & $21,543.2$ & $19,605.2$ & 50.1 & 54.2 \\
\hline Aggregate & 66.1 & 26.7 & -39.1 & -12.3 & $139,192.3$ & $115,829.1$ & 9538.4 & 8090.1 & 20.0 & 22.7 \\
\hline \multicolumn{11}{|c|}{ Representative Agricultural Pathways } \\
\hline Rawalpindi & 58.2 & 17.4 & -20.9 & -3.6 & $310,225.9$ & $294,968.5$ & $28,642.0$ & $27,356.7$ & 36.3 & 38.2 \\
\hline Chakwal & 55.7 & 21.8 & -24.8 & -3.0 & $322,270.2$ & $308,902.7$ & $33,937.1$ & $32,613.4$ & 32.0 & 33.1 \\
\hline Layyah & 50.9 & 17.1 & -17.4 & -0.4 & $275,166.0$ & $273,821.4$ & $26,460.3$ & $26,342.7$ & 39.0 & 38.9 \\
\hline Aggregate & 55.1 & 18.8 & -21.2 & -2.4 & $302,723.9$ & $292,618.8$ & $12,383.0$ & $11,953.8$ & 14.9 & 15.4 \\
\hline
\end{tabular}

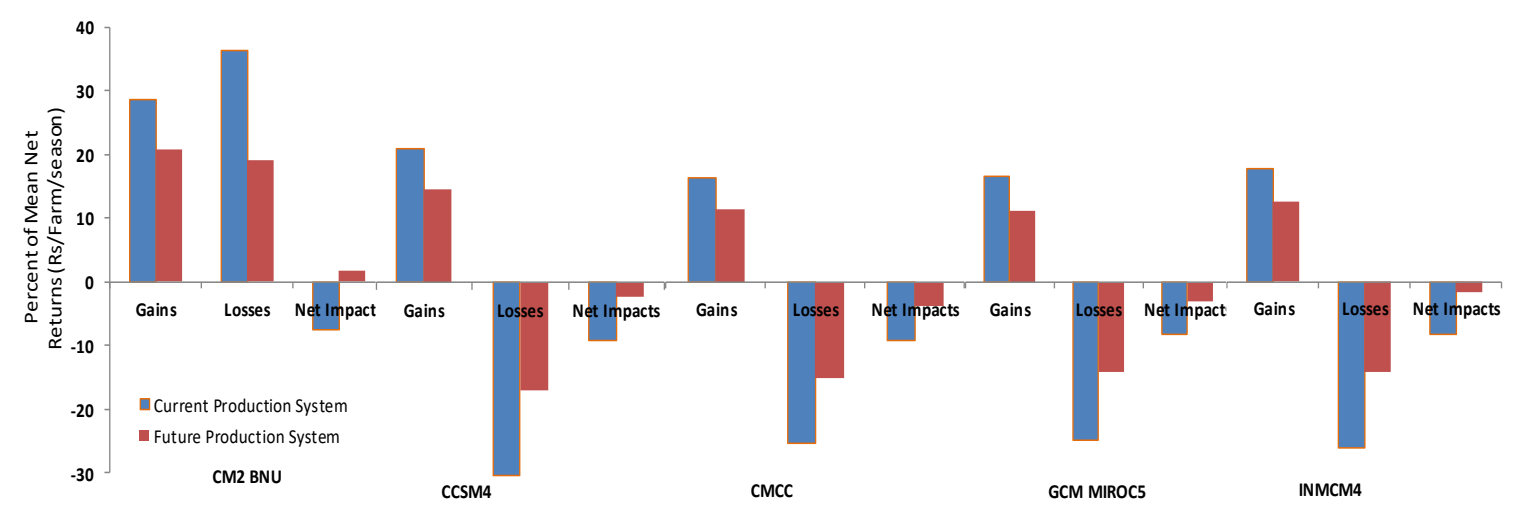

Figure 1. Mean net farm returns for current and future agricultural production systems.

\section{Discuss and Conclusions}

Climate variabilities significantly impact marginal farmers. These changes increase their poverty levels overtime. RMSE values of wheat yield varied from 261 to $305 \mathrm{~kg} / \mathrm{ha}$, and the value of the $d$-index ranged between 0.91 and 0.94 for all five selected GCMs. Results of the study showed that, for the case of climate change impacts, a minimum of $60 \%$ of farms would face a reduction in output. These reductions in farming output would ultimately negatively impact the livelihood indicators of farmers. Resultantly observed net returns and per capital income would decrease and poverty would increase. In this scenario, net farming returns with the existing climate would be PKR $0.14 \mathrm{M}$ for each farm. The findings depict that, for the perturbed climate case, estimated farm outcomes could decrease to PKR $0.12 \mathrm{M}$ for farmers. With respect to the increase in poverty, one-fifth of farmers are currently on or below the line of poverty; however, due to the adverse impacts of climate variations, poverty would increase with about one-fourth of the household vulnerable to these variations. If these changes continue, farming will become less profitable as poverty situations worsen. Similar quantifications were observed by References $[58,59]$ for Pakistan, and analogous poverty rates (in the form of percentages) were quantified by Reference [60] in the study of the IGB region of India.

Findings for the future production system revealed that the number of vulnerable household/farms would be between $46 \%$ and $62 \%$ due to climate change. This means that up to two-thirds of the population would be under the threat of these variations in the future despite considering future technological improvements. Estimated farm revenues with the present climate were PKR $0.3 \mathrm{M} / \mathrm{farm}$ and, in the case of climate change, these values varied from PKR 0.28 to $0.31 \mathrm{M}$ for each farming household. Due to variations in climate, $15 \%$ of the total selected farmers would be on or below the line of poverty, and, in the case of CC, poverty percentage would vary from $14 \%$ to $16 \%$ for all five selected GCMs. These findings were consistent with the study of Reference [61]. It is anticipated that a similar variation of these variables will be witnessed in the other farming systems of Pakistan. Poverty ranges were consistent with the finding of Reference [7]. 
Climate variabilities are worsening the poverty levels of poor communities in the agriculture sector. There is a need to adapt to these changes, and the government should take some urgent steps to tackle this danger. To minimize the negative responses of current and future climatic changes with regard to the farming sector, it is necessary to work on, develop, and endorse climate-resilient farming practices and inputs. RAP analysis suggests the need for policies to safeguard defensive investments for farmers in the study area, because this is the only way through which farming communities can be protected from these threats. Most importantly, the government should intervene in building the adaptive capacity of farmers by providing information on adaptation techniques through easily available means. Information on adaptation should be spread by the government using human resources, information technology, and infrastructure. This research can be propagated along different regional level pathways, and their effects can also be quantified. For improving the analysis outcomes, the same research can be conducted using alternative RAPs that were not taken into consideration here for mixed and cotton-wheat zones.

Author Contributions: Conceptualization, S.A.A.N., and A.M.N.; methodology, S.A.A.N., and M.A.I.; writing — review and editing, S.A.; writing—original draft preparation, A.N.

Funding: This study was not supported by any funding agency.

Acknowledgments: Authors are highly thankful to all those who participated and helped for this study, especially to Ishfaq Ahmad, Assistant Professor, Centre for Climate Research and Development (CCRD), COMSATS University Islamabad, Pakistan for his contribution in this paper related to bio-physical modelling.

Conflicts of Interest: The authors declare no conflicts of interest.

\section{References}

1. Chen, X.; Cui, Z.; Fan, M.; Vitousek, P.; Zhao, M.; Ma, W.; Wang, Z.; Zhang, W.; Yan, X.; Yang, J.; et al. Producing more grain with lower environmental costs. Nature 2014, 514, 486-489. [CrossRef]

2. Parry, M. The implications of climate change for crop yields, global food supply and risk of hunger. J. SAT Agric. Res. 2007, 4, 1-44.

3. Agrawal, A.; McSweeney, C.; Perrin, N. Local Institutions and Climate Change Adaptation. 2008. Available online: http://hdl.handle.net/10986/11145 (accessed on 10 November 2018).

4. Parry, M.L.; Rosenzweig, C.; Iglesias, A.; Livermore, M.; Fischer, G. Effects of climate change on global food production under SRES emissions and socio-economic scenarios. Glob. Environ. Chang. 2004, 14, 53-67. [CrossRef]

5. Aksan, Z:; Çelikler, D. The Turkish adaptation study of global warming questionnaire. Procedia Soc. Behav. Sci. 2012, 31, 681-684. [CrossRef]

6. Ashfaq, M.; Skinner, C.B.; Diffenbaugh, N.S. Influence of SST biases on future climate change projections. Clim. Dyn. 2011, 36, 1303-1319. Available online: https://link.springer.com/article/10.1007/s00382-010-0875-2 (accessed on 10 November 2018). [CrossRef]

7. Baig, I.; Ashfaq, M.; Hassan, S.; Mushtaq, K. Impact of financial reforms in irrigation sector of Punjab, Pakistan. J. Anim. Plant Sci. (Pak.) 2008, 18, 145-150.

8. Bennett, A.J.; Bending, G.D.; Chandler, D.; Hilton, S.; Mills, P. Meeting the demand for crop production: The challenge of yield decline in crops grown in short rotations. Biol. Rev. 2012, 87, 52-71. [CrossRef] [PubMed]

9. Bhutto, A.W.; Bazmi, A.A. Sustainable agriculture and eradication of rural poverty in Pakistan. Nat. Resour. Forum 2007, 31, 253-262. [CrossRef]

10. Enete, A.A.; Amusa, T.A. Challenges of agricultural adaptation to climate change in Nigeria: A synthesis from the literature. Field Actions Science Reports. J. Field Actions 2010, 4. Available online: http: //factsreports.revues.org/678 (accessed on 10 November 2018).

11. Farhangfar, S.; Bannayan, M.; Khazaei, H.R.; Baygi, M.M. Vulnerability assessment of wheat and maize production affected by drought and climate change. Int. J. Disaster Risk Reduct. 2015, 13, 37-51. [CrossRef]

12. Goddard, L.; Barnston, A.; Mason, S. Evaluation of the IRI's "net assessment" seasonal climate forecasts: 1997-2001. Bull. Am. Meteorol. Soc. 2003, 84, 1761-1782. [CrossRef]

13. Heckman, J. Varieties of selection bias. Am. Econ. Rev. 1990, 80, 313-318. Available online: https: //www.jstor.org/stable/2006591 (accessed on 10 November 2018). 
14. Honda, Y.; Kondo, M.; McGregor, G.; Kim, H.; Guo, Y.L.; Hijioka, Y.; Yoshikawa, M.; Oka, K.; Takano, S.; Hales, S.; et al. Heat-related mortality risk model for climate change impact projection. Environ. Health Prev. Med. 2014, $19,56$. [CrossRef] [PubMed]

15. Lobell, D.B.; Schlenker, W.; Costa-Roberts, J. Climate trends and global crop production since 1980. Science 2011, 1204531. [CrossRef] [PubMed]

16. Yasmin, B.; Jehan, Z. Trade liberalization and economic development: Evidence from Pakistan. Lahore J. Econ. 2006, 11, 19-34. [CrossRef]

17. Lone, R.A. Agricultural Diversification Towards High Value Commodities in South Asia. Int. J. Trade Glob. Bus. Perspect. 2013, 2, 688 .

18. Ahmad, A.; Ashfaq, M.; Rasul, G.; Wajid, S.A.; Khaliq, T.; Rasul, F.; Saeed, U.; Rahman, M.H.U.; Hussain, J.; Baig, I.; et al. Impact of climate change on the rice-wheat cropping system of Pakistan. In Handbook of Climate Change and Agroecosystems: The Agricultural Model Intercomparison and Improvement Project Integrated Crop and Economic Assessments; World Scientific: Singapore, 2015; pp. 219-258. [CrossRef]

19. Farooqi, A.B.; Khan, A.H.; Mir, H. Climate change perspective in Pakistan. Pak. J. Meteorol. 2005, 2, 11-21.

20. Mekonnen, M.M.; Hoekstra, A.Y. Four billion people facing severe water scarcity. Sci. Adv. 2016, 2, e1500323. [CrossRef] [PubMed]

21. Kreft, S.; Eckstein, D.; Junghans, L.; Kerestan, C.; Hagen, U. Global Climate Risk Index 2015: Who Suffers Most from Extreme Weather Events? Weather-Related Loss Events in 2013 and 1994 to 2013; Germanwatch e.V.: Bonn, Germany; Berlin, Germany, 2014.

22. Armah, F.A.; Yawson, D.O.; Yengoh, G.T.; Odoi, J.O.; Afrifa, E.K. Impact of floods on livelihoods and vulnerability of natural resource dependent communities in Northern Ghana. Water 2010, 2, 120-139. [CrossRef]

23. Kreft, S.; Eckstein, D.; Junghans, L.; Kerestan, C.; Hagen, U. Global Climate Risk Index 2014. Who Suffers Most from Extreme Weather Events, Weather-Related Loss Events in 2012 and 1993 to 2012; Germanwatch e.V.: Bonn, Germany; Berlin, Germany, 2013.

24. Eriksen, S.H.; Kelly, P.M. Developing credible vulnerability indicators for climate adaptation policy assessment. Mitig. Adapt. Strateg. Glob. Chang. 2007, 12, 495-524. [CrossRef]

25. Godfray, H.C.J.; Beddington, J.R.; Crute, I.R.; Haddad, L.; Lawrence, D.; Muir, J.F.; Toulmin, C. Food security: The challenge of feeding 9 billion people. Science 2010, 327, 812-818. [CrossRef] [PubMed]

26. Hermans, C.; Geijzendorffer, I.; Ewert, F.; Metzger, M.; Vereijken, P.; Woltjer, G.; Verhagen, A. Exploring the future of European crop production in a liberalised market, with specific consideration of climate change and the regional competitiveness. Ecol. Model. 2010, 221, 2177-2187. [CrossRef]

27. Cosentino, S.L.; Testa, G.; Scordia, D.; Alexopoulou, E. Future yields assessment of bioenergy crops in relation to climate change and technological development in Europe. Ital. J. Agron. 2012, 7, 22. [CrossRef]

28. Leiserowitz, A. International public opinion, perception, and understanding of global climate change. Hum. Dev. Rep. 2007, 2008, 1-40.

29. Tynkkynen, N. A great ecological power in global climate policy? Framing climate change as a policy problem in Russian public discussion. Environ. Politics 2010, 19, 179-195. [CrossRef]

30. Cammarano, D.; Hawes, C.; Squire, G.; Holland, J.; Rivington, M.; Murgia, T.; Ronga, D. Rainfall and temperature impacts on barley (Hordeum vulgare L.) yield and malting quality in Scotland. Field Crop. Res. 2019, 241, 107559. [CrossRef]

31. Mertz, O.; Halsnæs, K.; Olesen, J.E.; Rasmussen, K. Adaptation to climate change in developing countries. Environ. Manag. 2009, 43, 743-752. [CrossRef]

32. Aslam, A.Q.; Ahmad, S.R.; Ahmad, I.; Hussain, Y.; Hussain, M.S. Vulnerability and impact assessment of extreme climatic event: A case study of southern Punjab, Pakistan. Sci. Total Environ. 2017, 580, 468-481. [CrossRef]

33. Salma, S.; Shah, M.; Rehman, S. Rainfall trends in different climate zones of Pakistan. Pak. J. Meteorol. 2012, 9. [CrossRef]

34. Ali, A. Coping with climate change and its impact on productivity, income, and poverty: Evidence from the Himalayan region of Pakistan. Int. J. Disaster Risk Reduct. 2017, 24, 515-525.

35. Ali, A.; Erenstein, O. Assessing farmer use of climate change adaptation practices and impacts on food security and poverty in Pakistan. Clim. Risk Manag. 2017, 16, 183-194. [CrossRef] 
36. Ashfaq, M.; Zulfiqar, F.; Sarwar, I.; Quddus, M.A.; Baig, I.A. Impact of climate change on wheat productivity in mixed cropping system of Punjab. Soil Environ. 2011, 30, 110-114.

37. Mall, R.; Singh, R.; Gupta, A.; Srinivasan, G.; Rathore, L. Impact of climate change on Indian agriculture: A review. Clim. Chang. 2006, 78, 445-478. [CrossRef]

38. Masutomi, Y.; Takahashi, K.; Harasawa, H.; Matsuoka, Y. Impact assessment of climate change on rice production in Asia in comprehensive consideration of process/parameter uncertainty in general circulation models. Agric. Ecosyst. Environ. 2009, 131, 281-291. [CrossRef]

39. Sattar, R.; Wang, S.; Tahir, M.; Cadwell, C. Assessment of Smallholder Farmers Vulnerability Due to Climate Change in Arid Areas of Pakistan. Appl. Ecol. Environ. Res. 2017, 15, 291-312. [CrossRef]

40. Arshad, M.; Amjath-Babu, T.; Aravindakshan, S.; Krupnik, T.J.; Toussaint, V.; Kächele, H.; Müller, K. Climatic variability and thermal stress in pakistan's rice and wheat systems: A stochastic frontier and quantile regression analysis of economic efficiency. Ecol. Indic. 2018, 89, 496-506. [CrossRef]

41. Abid, M.; Schneider, U.A.; Scheffran, J. Adaptation to climate change and its impacts on food productivity and crop income: Perspectives of farmers in rural Pakistan. J. Rural Stud. 2016, 47, 254-266. [CrossRef]

42. Gorst, A.; Dehlavi, A.; Groom, B. Crop productivity and adaptation to climate change in Pakistan. Environ. Dev. Econ. 2018, 23, 679-701. [CrossRef]

43. Weldearegay, S.K.; Tedla, D.G. Impact of climate variability on household food availability in Tigray, Ethiopia. Agric. Food Secur. 2018, 7, 6. [CrossRef]

44. Chalise, S.; Naranpanawa, A.; Bandara, J.S.; Sarker, T. A general equilibrium assessment of climate change-induced loss of agricultural productivity in Nepal. Econ. Model. 2017, 62, 43-50. [CrossRef]

45. Menike, L.; Arachchi, K.K. Adaptation to climate change by smallholder farmers in rural communities: Evidence from Sri Lanka. Procedia Food Sci. 2016, 6, 288-292. [CrossRef]

46. Yang, Y.C.E.; Brown, C.M.; Yu, W.H.; Savitsky, A. An introduction to the IBMR, a hydro-economic model for climate change impact assessment in Pakistan's Indus River basin. Water Int. 2013, 38, 632-650. [CrossRef]

47. Ahmad, M.; Nawaz, M.; Iqbal, M.; Javed, S. Analysing the Impact of Climate Change on Rice Productivity in Pakistan. 2014. Available online: https://mpra.ub.uni-muenchen.de/72861/3/MPRA_paper_72861.pdf (accessed on 16 September 2018).

48. Shakoor, U.; Saboor, A.; Ali, I.; Mohsin, A. Impact of climate change on agriculture: Empirical evidence from arid region. Pak. J. Agric. Sci. 2011, 48, 327-333.

49. Janjua, P.Z.; Samad, G.; Khan, N.U.; Nasir, M. Impact of climate change on wheat production: A case study of Pakistan [with comments]. Pak. Dev. Rev. 2010, 49, 799-822. [CrossRef]

50. Hussain, S.S.; Mudasser, M. Prospects for wheat production under changing climate in mountain areas of Pakistan-An econometric analysis. Agric. Syst. 2007, 94, 494-501. [CrossRef]

51. Jones, J.W.; Hoogenboom, G.; Porter, C.H.; Boote, K.J.; Batchelor, W.D.; Hunt, L.; Wilkens, P.W.; Singh, U.; Gijsman, A.J.; Ritchie, J.T. The DSSAT cropping system model. Eur. J. Agron. 2003, 18, 235-265. [CrossRef]

52. Rosenzweig'kil, C.; Jonesi, J.W.; Hatfie1d, J.L.; Mutterl, C.Z. The Agricultural Model Intercomparison and Improvement Project (AgMIP): Integrated regional assessment projects. In Handbook of Climate Change and Agroecosystems: Global and Regional Aspects and Implications; Joint Publication with the American Society of Agronomy, Crop Science Society of America, and Soil Science Society of America; World Scientific: Singapore, 2013; pp. 263-280. [CrossRef]

53. Antle, J.M.; Valdivia, R.O. Modelling the supply of ecosystem services from agriculture: A minimum-data approach. Aust. J. Agric. Resour. Econ. 2006, 50, 1-15. [CrossRef]

54. Claessens, L.; Antle, J.; Stoorvogel, J.; Valdivia, R.; Thornton, P.K.; Herrero, M. A method for evaluating climate change adaptation strategies for small-scale farmers using survey, experimental and modeled data. Agric. Syst. 2012, 111, 85-95. [CrossRef]

55. Baig, I.A.; Ashfaq, M.; Naqvi, S.A.A.; Ahmed, A.; Hoogenboom, G.; Antle, J.M.; Valdivia, R. Ex ante impact assessment of wheat crop in Punjab-Pakistan. J. Appl. Environ. Biol. Sci. 2014, 4, 358-363. Available online: https://www.researchgate.net/publication/283353561 (accessed on 10 September 2018).

56. Valdivia, R.O.; Antle, J.M.; Stoorvogel, J.J. Coupling the Tradeoff Analysis Model with a market equilibrium model to analyze economic and environmental outcomes of agricultural production systems. Agric. Syst. 2012, 110, 17-29. [CrossRef] 
57. Moss, R.H.; Edmonds, J.A.; Hibbard, K.A.; Manning, M.A.; Rose, S.K.; van Vuuren, D.P.; Carter, T.R.; Emori, S.; Kainuma, M.; Kram, T.; et al. The next generation of scenarios for climate change research and assessment. Nature 2010, 463, 747-756. [CrossRef] [PubMed]

58. Hanif, U.; Syed, S.H.; Ahmad, R.; Malik, K.A. Economic impact of climate change on agricultural sector of Punjab. Pak. Dev. Rev. 2010, 49, 771-798. [CrossRef]

59. Iqbal, M.M. Climate Change Impacts on Agriculture and Building Resilience in Pakistan. Workshop on Developing Farming Systems for Climate Change Mitigation. 2013. Available online: www.adbi.org (accessed on 10 September 2018).

60. Subash, N.; Gangwar, B.; Singh, H.; Baigorria, G.; Sikka, A.K.; Valdivia, R.O. Integrated Climate Change Assessment through Linking Crop Simulation with Economic Modeling-Results from the Indo-Gangetic Basin. In Handbook of Climate Change and Agroecosystems; Imperial College Press: London, UK; The American Society of Agronomy: Madison, WI, USA, 2015.

61. Jehangir, W.A.; Masih, I.; Ahmed, S.; Gill, M.A.; Ahmad, M.; Mann, R.A.; Chaudhary, M.R.; Qureshi, A.S.; Turral, H. Sustaining Crop Water Productivity in Rice-Wheat Systems of South Asia: A Case Study from the Punjab, Pakistan; IWMI Working Paper 115; International Water Management Institute: Colombo, Sri Lanka, 2007; p. 45 .

(C) 2019 by the authors. Licensee MDPI, Basel, Switzerland. This article is an open access article distributed under the terms and conditions of the Creative Commons Attribution (CC BY) license (http://creativecommons.org/licenses/by/4.0/). 